\title{
Correction to: An efficient transgene-free DNA-editing system for Arabidopsis using a fluorescent marker
}

\author{
Lejun Ouyang $\mathbb{D} \cdot$ Mingsai Ma $\cdot$ Limei Li
}

Published online: 20 December 2019

(C) Springer Nature B.V. 2019

\section{Correction to: Biotechnol Lett}

https://doi.org/10.1007/s10529-019-02778-z

The article An efficient transgene-free DNA-editing system for Arabidopsis using a fluorescent marker, written by Lejun Ouyang, Mingsai Ma and Limei Li, was originally published electronically on the publisher's internet portal (currently SpringerLink) on 03 December 2019 with open access. With the author(s)' decision to step back from Open Choice, the copyright of the article changed on 18 December 2019 to (C) Springer Nature B.V. 2019 and the article is forthwith distributed under the terms of copyright. The original article has been corrected.

Publisher's Note Springer Nature remains neutral with regard to jurisdictional claims in published maps and institutional affiliations.

The original article can be found online at https://doi.org/10.1007/s10529-019-02778-z.

L. Ouyang $(\varangle) \cdot$ M. Ma $\cdot$ L. Li

College of Biological and Food Engineering, Guangdong

University of Petrochemical Technology, No. 129,

Guangdu Road, Maoming 525000, Guangdong, China

e-mail: ouyanglejun@163.com

L. $\mathrm{Li}$

e-mail: lilimeinh@163.com 